\title{
TAMPEREEN SOSIAALISEN KUNTOUTUKSEN MALLILLA TOIMINTAKYKYÄ
}

\author{
Palvelumallin kuvaus ja kyselyaineiston analyysi
}

\section{Johdanto}

Mittava työttömyys, elinajan pidentyminen ja julkisen talouden kestävyys haastavat päättäjiä. Rakenneongelmiin vastattaessa huolehditaan yksilöiden hyvinvoinnista ja heidän onnen edellytyksistään. Keppi ja porkkana ovat työllisyyden edistämisen kaksi välinettä. Työmarkkinoiden syrjällä ja ulkopuolella olevien kohdalla keppi ei kuitenkaan ole mielekäs menetelmä, koska kyseistä asiakasjoukkoa määrittelevät työllistymistäkin suuremmat kysymykset. Vaikeimmin työllistettävien kohdalla toteutetaan kuntouttavaa työtoimintaa. Kriittisimmät puhuvat kuntouttavan työtoiminnan kohdalla tempputyöllistämisestä. Kuitenkin vaikeimmin työllistyvien asiakkaiden ongelmien äärellä paljastuu, että vapaaehtoisuuteen nojaavassa kuntouttavassa ryhmätyössä todellinen temppu on se, miten toimintamuoto saa aikaan niin paljon hyvää pienillä kustannuksilla. Vaikeimmin syrjäytyneiden kohdalla on kyse usein kallishoitoisista ja kärsimystä aiheuttavista sairauksista sekä ylisukupolvisista vaikutuksista, jotka näkyvät lastensuojelussa ja tulevien sukupolvien heikossa suorituskyvyssä. Tämä teksti kertoo siitä, miksi porkkanaa käyttävä Tampereen sosiaalisen kuntoutuksen malli on taloudellinen, inhimillinen ja tehokas.
"Elämän ennakoitavuus, vastavuoroiset suhteet, merkityksellisyyden kokemukset ja itsenäisyys vahvistavat yhdessä yksilöllisten voimavarojen kanssa köyhien turvaverkkoa, joka estää heitä putoamasta pystymättömyyden tunteeseen ja auttaa taistelemaan aineetonta köyhyyttä vastaan. Köyhän voimavarat ja yhteydet mahdollisuuksiin ovat kuitenkin hentoja. Vaikka ne ovat tavalla tai toisella jatkuvasti olemassa, lannistuminen ja voimattomuus muuttavat turvaverkon herkästi näkymättömäksi.” (Anna-Maria Isola, Elina Turunen ja Heikki Hiilamo 2016: Miten köyhät selviytyvät Suomessa?)

Kansainvälinen tutkimus interventioista, joilla pyritään kohentamaan työttömien asemaa, keskittyy yhtäältä työttömien työllistettävyyden lisäämiseen esimerkiksi työnhakutaitojen parantamisen avulla ja toisaalta siihen, miten interventiot lievittävät työttömyyden kielteisiä vaikutuksia mielialaan ja hyvinvointiin (Hodzic ym. 2015). Varovaisen positiivisia tuloksia on saatu interventioista, joissa on tuettu työttömien voimaantumista (Bhat 2010), tunneälytaitoja (Hodzic ym. 2015), sel- 
viytymismekanismeja (Creed ym. 1999) sekä hyvinvointia ja minäpystyvyyden tunnetta (Machin \&t Creed 2003). Suomessa Työhön-ohjelma tuki osallistujien työnhakupystyvyyden tunnetta ja kykyä selviytyä tulevista vastoinkäymisistä. Ohjelma vähensi näiden kompetenssien kautta työttömien masennusoireita (Silvonen \&t Vuori 1998). Työttömien psykologinen tukeminen on yksi merkittävä taustaulottuvuus myös Tampereen mallissa.

Tampereen kaupunki aloitti vuonna 2012 sosiaalisen kuntoutuksen osana aikuissosiaalityötä. Toiminta tunnetaan nykyisin nimellä "Avaimia arkeen" (Tampereen kaupunki 2016; Avaimia arkeen -esite). Kyseessä on vuonna 2015 voimaan tulleen sosiaalihuoltolain pykälän 17 mukainen toiminta, jossa "sosiaalisella kuntoutuksella tarkoitetaan sosiaalityön ja sosiaaliohjauksen keinoin annettavaa tehostettua tukea sosiaalisen toimintakyvyn vahvistamiseksi, syrjäytymisen torjumiseksi ja osallisuuden edistämiseksi”. Tampereen mallin toiminta toteutuu kuntouttavan työtoiminnan lain puitteissa. Toimintamuoto tavoittelee inhimillistä hyvää ja taloudellista kestävyyttä.

On muodikasta puhua etsivästä nuorisotyöstä. Tampereen sosiaalinen kuntoutus soveltaa etsivää otetta aikuisiin. Asiakashankinnassa yhdistellään useita yhteistyöpintoja ja -kanavia. Kelan yhteistyökumppaneina (työmarkkinatuen kuntarahoituksen osalta) kunnan sosiaalityöntekijät ovat lähestyneet kirjeellä työmarkkinatukea pitkään saaneita tamperelaisia. Heille on tarjottu vapaaehtoista mahdollisuutta osallistua sosiaaliseen kuntoutukseen. Samoin työllisyyspalvelut - niin työllisyydenhoidon yksikössä (Tampereella TYPA) kuin TE-toimistossa - ovat tiedottaneet mahdollisuudesta.

Tampereen sosiaalinen kuntoutus on ryhmätoimintaa kerran viikossa neljän tunnin ajan. Kukin ryhmä kestää kolme kuukautta eli kokoontumisia on 13 kertaa. Pääosa osallistujista on työttömiä työhakijoita, mutta ryhmään osallistuu myös joitakin työkyvyttömyyseläkkeellä olevia. Pääsääntöisesti ryhmätoimintaan osallistuessaan työtön työnhakija on oikeutettu työmarkkinatukeen. Aloitusta edeltää aktivointisuunnitelma, jossa hahmo- tellaan yhdessä asiakkaan, TE-toimiston ja sosiaalityöntekijän kesken asiakkaalle työllistymisen ja kuntoutumisen suunnitelma. Useita asiakkaita innostaa mukaan myös se, että osallistuminen täyttää työttömyysturvaan liittyvää työssäolovelvoitetta.

Tämän katsauksen tarkoitus on tarkastella Tampereen mallia yksityiskohtaisesti. Analysoimme asiakaskyselyä ja mallin keskeisiä ulottuvuuksia. Tarkastelun päämäärä on tunnistaa mallin hyviä käytäntöjä, jotta niihin voidaan peilata maan muissa kunnissa käytössä olevia toimia siinä, miten työmarkkinoiden syrjällä ja ulkopuolella olevia ihmisiä voidaan tehokkaasti kuntouttaa.

\section{Aineisto ja menetelmät}

Tutkimuksen metodisena viitekehyksenä oli toimintatutkimus. Tutkija (M.P.) työskenteli kehittäjä-sosiaalityöntekijänä hankkeessa Tampereella vuoden ajan huhtikuusta 2013 toukokuuhun 2014. Hän ei toiminut ryhmän ohjaajana, mikä antaa tarvittavan etäisyyden tarkasteltavaan ilmiöön. Toisaalta kehittäjäsosiaalityöntekijän rooli asiakkaiden alkuhaastattelijana ja ryhmien profiilien muodostajana mahdollisti toiminnan monipuolisen havainnoimisen. Kehittäjä-sosiaalityöntekijä teki myös vierailun ryhmätoiminnan puolivälissä kuhunkin ryhmään. Mallin laadullinen kuvaus perustuu pääosin näissä rooleissa tehtyihin havaintoihin.

Täydennämme mallin laadullista kuvausta asiakaskyselyn tiedoilla. Mallinkuvauksemme erittelee vuoden 2015 asiakasjoukkoa ( $\mathrm{N}=802$ ). Tästä poiketen sosiaalisen kuntoutuksen koettua merkitystä voimme arvioida laajemmalla

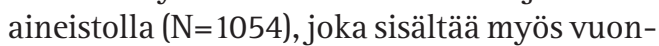
na 2014 sosiaaliseen kuntoutukseen osallistuneita. Koska ryhmän koetun merkityksen arvioinnit on tehty kuntoutusryhmissä yleensä kahden viimeisen osallistumiskerran aikana, on selvää, että kaikilta kuntoutuksen läpikäyneiltä ei ole saatu arviota. Toimintaan osallistuneen sosiaalityöntekijä-tutkijan arvio tämän kadon määrästä on 10-20 prosenttia.

Vuoden 2015 asiakkaista $(\mathrm{N}=802)$ miehiä oli 54 prosenttia ja naisia 46 prosenttia. Aloi- 
tetun kuntoutuksen keskeytti 12 prosenttia. Jakson keskeytti ilman pätevää syytä viisi prosenttia. Perusteellinen alkuhaastattelu ja asiakkaan tarpeiden huomioiminen ryhmäsijoituksessa pienentävät keskeytysprosenttia. Pätevän syyn vuoksi keskeyttäneitä on laskettu mukaan jatko-ohjaustilastoihin, joita eritellään myöhemmin tässä katsauksessa. Alle 30-vuotiaiden osuus oli 14 prosenttia ja yli 30-vuotiaiden 86 prosenttia, mikä kertoo siitä, että hanke keskittyi nuoria aikuisia iäkkäämpiin kuntoutettaviin.

\section{Tulokset}

\section{Tampereen mallin keskeiset piirteet}

Keskeistä Tampereen mallissa on, että se perustuu ryhmätoimintaan. Ryhmän koko on enintään 12 henkilöä. Ryhmän kokoontuminen kerran viikossa neljän tunnin ajan mahdollistaa huomattavan määrän samanaikaisia ryhmiä. Tämä varmistaa mahdollisimman monelle nopeasti paikan ryhmässä. Perusryhmissä käsitellään muun muassa terveyteen, arjen sujuvuuteen, ihmissuhteisiin, päihteisiin ja työllistymisvaihtoehtoihin liittyviä kysymyksiä. Jatkoryhmissä painopiste on kullekin sopivan työ- ja koulutusreitin suunnittelussa. Ryhmässä toteutuu vertaistuen ja asiantuntija-avun yhdistelmä, jonka tarkoitus on lisätä asiakkaan ymmärrystä omasta tilanteestaan. Ryhmätoiminta vahvistaa osallistujan sosiaalisia taitoja ja itsetuntoa, arjessa pärjäämistä ja vastuunottoa omasta elämästä. Osalla ryhmäkerroista tehdään vierailuja palveluihin. Kodin läheisyys tai sujuva kulkuyhteys on mahdollista huomioida, koska ryhmiä järjestetään eri puolilla Tamperetta.

Monet sosiaalisen kuntoutuksen ryhmistä ovat niin sanottuja sekaryhmiä. Näiden lisäksi on jollakin ominaisuudella määriteltyjä ryhmiä, jotta liiallinen erilaisuus ei haittaisi tehokasta kuntoutumista. Ikä on ollut yksi jakoperuste. Nuorille suunnatun palvelun lisäksi eläkeiän tuntumassa oleville, elämäänsä hyvin hallitseville on oma ryhmänsä, samoin kuin vähän suomen kieltä osaaville maahanmuuttajille. Myöskin päihdeongelmaisille on oma erityisryhmänsä. Sosiaalipsykiatriseen kuntoutukseen erikoistunut paikallinen järjestö on tarjonnut ryhmää jännittäjille ja avohoidolla tuettavista mielenterveysongelmista kärsiville.

Taulukko 1 tiivistää Tampereen mallin sellaiset piirteet, jotka ovat näkemyksemme mukaan keskeisiä toiminnan soveltamiseksi muihin konteksteihin.

Anne Kuvaja (2012) perustelee motivaatiokysymysten tärkeyttä sosiaalisessa kuntoutuksessa. Tampereen mallin lähtökohtana ovat sosiaalityö ja järkevä yhteiskuntapolitiikka. Asiakkaan motivaation kannalta työntekijän ja asiakkaan vuoropuhelu on tärkeää. Koska osallistuminen on vapaaehtoista, jo mukaan lähtö osoittaa motivaatiota, halua muutokseen. Päihderiippuvaisten kohdalla motivoinnilla on suuri merkitys. Periaatteessa alkoholiriippuvaiselta vaaditaan vain yksi selvä nelituntinen viikossa. Kuitenkin ryhmään osallistumisessa onnistuminen saattaa merkitä isoa muutosta elämässä, esimerkiksi johtaa merkittävään päihteiden käytön vähentämiseen. Opioidikorvaushoidossa olevalta edellytetään vakaata tilannetta päihteidenkäytön osalta. Tämä varmistetaan suunnitteluvaiheen tiiviillä yhteistyöllä hoitavan tahon kanssa. Pääsy sosiaalisen kuntoutuksen ryhmään kannustaa vastuunottoon ja oman päihderiippuvuuden haastamiseen tai hallitsemiseen.

Asiakkaan osallistumiselle on useita kannustimia. Hän saa kulukorvauksen (yhdeksän euroa) läsnäolokerroilta. Ryhmätoiminnan ajaksi on käytössä Tampereen kaupunkiliikenteen työmatkalippu (50 matkaa/30 vrk). Ryhmäkerroilla tarjotaan aamukahvi ja lounas, mikä motivoi osallistumiseen ja päivärytmin ylläpitoon.

Sosiaalisen kuntoutuksen ryhmä tukee osallisuutta. Yhtäältä tähdätään hyvinvoinnin lisääntymiseen ja toisaalta suurelle osalle asiakkaita muodostetaan suunnitelma kohti työtä tai koulutusta. Jotta pitkään vailla työtä olleet ja vähäiseen toimeliaisuuteen tottuneet asiakkaat saadaan ryhmätoimintaan mukaan, on syytä lähteä liikkeelle varovasti. Vähittäisyys, esimerkiksi yksi 4-tuntinen päivä viikossa, on tehokasta kuntoutuksessa. Huu- 
Taulukko 1. Tiivistelmä Tampereen sosiaalisen kuntoutuksen mallista.

\begin{tabular}{|c|c|}
\hline \multirow[t]{5}{*}{ Idea yleisellä tasolla } & Ryhmämuotoista toimintaa. \\
\hline & Aktivoida ja integroida pitkään työmarkkinoilta poissa olleita. \\
\hline & Tarjota mahdollisuuksia. \\
\hline & Osallisuus \\
\hline & "Pieni on suurta." \\
\hline Tuen muodot & Vertaistuen ja asiantuntija-avun yhdistelmä. \\
\hline Sosiaalinen tuki & Ryhmän käytännöllinen ja eksistentiaalinen merkitys. \\
\hline Laajuus & Massatuote, sopii laajoille joukoille. \\
\hline Asiakas & Heikossa työmarkkina-asemassa olevat. \\
\hline Organisoiva taho & Kunta \\
\hline Toteuttava taho & Järjestöt (pääosin), kunnan sosiaalityöntekijöiden tuella. \\
\hline Kumppanuus & $\begin{array}{l}\text { Useat tahot asiakasohjauksessa. } \\
\text { Työvoimahallinto aktivointisuunnitelman teossa; järjestöt (ja kunta) } \\
\text { toteutuksessa. }\end{array}$ \\
\hline Motivaatio & $\begin{array}{l}\text { Asiakkaat pääsevät ensisijaisen sosiaaliturvan kuten työttömyysturvan piiriin } \\
\text { kuntoutuksen ajaksi ja jotkut myös jakson jälkeen. }\end{array}$ \\
\hline Vastuu & Mahdollisuus ottaa vastuuta omasta elämästä. \\
\hline Materiaalisia etuja asiakkaalle & $\begin{array}{l}\text { Kulukorvaus } \\
\text { Työmatkalippu } \\
\text { Aamukahvi ja lounas } \\
\text { Työssäolovelvoitteen täyttyminen. }\end{array}$ \\
\hline Vaikutuksia instituutioihin & $\begin{array}{l}\text { Haastaa aikuissosiaalityötä, kuntouttavaa työtoimintaa ja työvoimahallintoa } \\
\text { kehittymään. } \\
\text { Tarjoaa mahdollisuuksia järjestöille. }\end{array}$ \\
\hline Suhde työhön & Asiakkaat voivat edetä toisiin kuntoutuspalveluihin ja kohti työelämää. \\
\hline Julkistalous & $\begin{array}{l}\text { Kuntataloudellisesti järkevää, valtio ottaa taloudellista vastuuta } \\
\text { aktivoituneista. } \\
\text { Pitkällä aikavälillä säästöt ovat todennäköisiä. }\end{array}$ \\
\hline Mitä tietoa tuotti? & $\begin{array}{l}\text { Asiakkaat haluavat olla aktiivisia. } \\
\text { Matalan kynnyksen palveluja tarvitaan. } \\
\text { Onnistumisen kokemus. } \\
\text { Merkityksellisyyden kokemus. }\end{array}$ \\
\hline
\end{tabular}

mekuntoutujien avokuntoutuksen yhteydessä olemme käyttäneet käsitettä vähäasiakkuus, joka viittaa siihen, että asiakkaalle on annettava aikaa rakentaa luottamusta palveluun (Perkiö \&t Simula 2004). Joskus vähemmän on enemmän. Kuntoutumista voi rinnastaa korkeushyppyyn. Kun haluamme oppia korkeushyppyä, on saatava aikaan onnistuneita hyppyjä. Eli rima on laitettava sille korkeudelle, että siitä voi hypätä yli. Rimaa voi taitojen karttuessa nostaa. Kuntoutuspalveluihin osallistumista ei saa tehdä vaikeaksi.

\section{Mitä sosiaalinen kuntoutus merkitsee asiakkaalle?}

Aulikki Kananoja $(2012,39)$ sanottaa sosiaalisen kuntoutuksen juuri siten, kuin se toteutuu Avaimia arkeen -ryhmätoiminnassa viikoittain. Näillä Kananojan mainitsemilla, alla luetelluilla ulottuvuuksilla asiakkaat kokevat menevänsä eteenpäin:

- identiteetin ja roolien muutokset

- ihmissuhteet, muun muassa perhesuhteet ja niiden muutokset 
Taulukko 2. Sosiaalisen kuntoutuksen koettu merkitys (vastaajia 1054).

\begin{tabular}{|l|l|l|}
\hline $\begin{array}{l}\text { Kysymys: Mitä ryhmä antoi minulle? } \\
\text { (2751 vastausta, enintään } 3 \text { vastausta/vastaaja. Vastaajia oli 1054.) }\end{array}$ & \multicolumn{2}{l|}{ Vastausten N } \\
\hline Vastaus & $\begin{array}{l}\text { Kuinka moni vastaaja } \\
\text { mainitsi asian? }\end{array}$ & 547 \\
\hline 1. Sain mielekästä tekemistä arkeeni & $52 \%$ & 521 \\
\hline 2. Uusia ihmissuhteita & $49 \%$ & 390 \\
\hline 3. Sain lisää tietoa erilaisista palveluista & $37 \%$ & 368 \\
\hline 4. Muodostin toimivan jatkosuunnitelman & $35 \%$ & 233 \\
\hline 5. Edisti psyykkistä tai fyysistä terveyttäni & $22 \%$ & 211 \\
\hline 6. Sain apua ja tietoa talousasioihin liittyen & $20 \%$ & 144 \\
\hline 7. Sain paremman käsityksen työkyvyistäni ja osaamisestani & $14 \%$ & 121 \\
\hline 8. Vähensin päihteiden käyttöä & $12 \%$ & 73 \\
\hline 9. Työnhakutaitoni paranivat & $7 \%$ & 66 \\
\hline 10. Kielitaito & $6 \%$ & 77 \\
\hline 11. Muu & $7 \%$ & \\
\hline Yhteensä & & 2751 \\
\hline
\end{tabular}

- harrastukset, ryhmäjäsenyydet, sitoutumiset

- sosiaalinen toimintakyky, arkielämän taidot, yhteiskunnan pelisäännöt

- osallisuus, liittymishalu ja -mahdollisuudet sekä vaikutusmahdollisuudet

- syrjäytymisriskit tai syrjäytymisen vähentäminen/poistaminen.

Kun asiakkaat $(\mathrm{N}=1054)$ valitsivat enintään kolme vaihtoehtoa kuvaamaan sitä, mitä sosiaalisen kuntoutuksen ryhmä on heille antanut, esille nousivat mielekäs tekeminen, ihmissuhteet ja tulevaisuuden suunnittelu (taulukko 2).

Tulokset siinä, mitä sosiaalisen kuntoutuksen asiakkaat pitävät keskeisenä, vastaavat aiempaa tutkimusta. Mira Haapamäki (2009) tutki pro gradu -työssään sosiaalista kuntoutusta asiakaslähtöisyyden näkökulmasta haastattelemalla Koutsi-projektin asiakkaita. Koutsi oli Kiipulasäätiön vuosina 2004-2008 hallinnoima projekti. Siinä keskiössä oli kehittää palvelutarvearviointia ja valmennusta, jotta asiakkaat pääsisivät sellaiseen ammattiin, jossa voi työllistyä. Haapamäen saamat tulokset osuvat samoihin kolmeen teemaan, jotka myös Tampereen asiakkaat kokivat tärkeiksi tehdyssä kyselyssä: elämänhallintaan, oman tilanteen selvittämiseen ja ryhmässä toimimisen tärkeyteen.
Asiakkaiden $(\mathrm{N}=1054)$ kokemusta omasta sosiaalisesta kuntoutumisestaan kysyttiin palautteessa kymmenportaisella asteikolla ( 1 = heikko, 10 = erittäin hyvä) kahden osa-alueen osalta. Yhtäältä kysyttiin arvioita elämänhallinnasta (kuvio 1) ja toisaalta työllistymis- ja koulutustilanteesta (kuvio 2). Asiakasta pyydettiin jakson lopulla arvioimaan tilannettaan näillä osa-alueilla ennen sosiaalisen kuntouksen jaksoa ja vastaamisen aikana eli jakson lopulla. Molemmissa ryhmissä asiakkaat kokivat merkittävää edistymistä.

\section{Kuntoutuspolku ja vaikuttavuus}

Taulukosta 3 käyvät ilmi sosiaalisen kuntoutuksen asiakkaiden $(\mathrm{N}=756)$ jatkosuunnitelmat. Noin yksi kolmesta (36\%) jatkaa viikoittaista useampipäiväistä osallistumista edellyttävään kuntouttavaan työtoimintaan. Yhtä moni jatkaa toisen jakson sosiaalisessa kuntoutuksessa. Näiden pääväylien lisäksi yhteensä $5 \%$ pääsee kiinni työhön, koulutukseen tai työkokeiluun. Jakson päättävistä asiakkaista syyperusteisiin palveluihin ohjautuu yksi kuudesta. Tällaisia palveluja ovat esimerkiksi eläkeselvittely ja terveydenhoitopalvelut. Jakson päättävistä kuudella prosentilla ei ollut käsitystä siitä, mitä he tekevät 


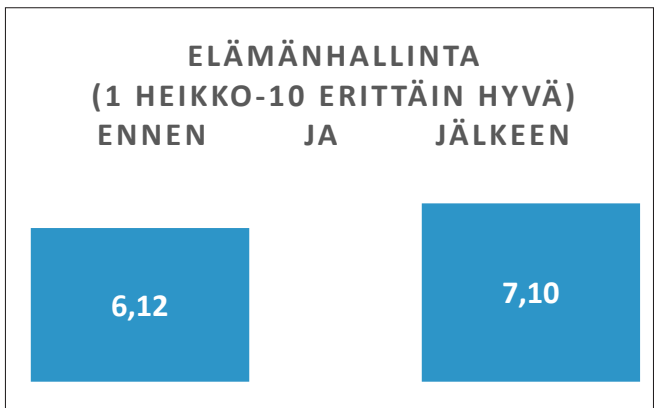

Kuvio 1. Koettu elämänhallinta ennen sosiaalisen kuntoutuksen jaksoa ja sen jälkeen.

jatkossa. Nämä jatko-ohjaustiedot ovat yhteneväisiä Tampereen mallia käsittelevän raportin kanssa: sosiaalisen kuntoutuksen palvelupolku on kuvattu myös Tampereen kaupungin sosiaalista kuntoutusta käsittelevän selvityksen loppuraportissa (Kesä ym. 2013, 10). Raportissa puhutaan sosiaalisen kuntouksen ryhmäpalvelusta, mikä tarkoittaa samaa kuin tässä tekstissä käytetty sosiaalisen kuntoutuksen käsite.

\section{Pohdinta}

Sosiaaliseen kuntoutukseen liittyvät olennaisesti taloudelliset kannusteet. Yleisillä sosiaalipoliittisilla linjauksilla on merkitystä. Asiakkaiden sosiaalisen kuntoutumisen kannal-

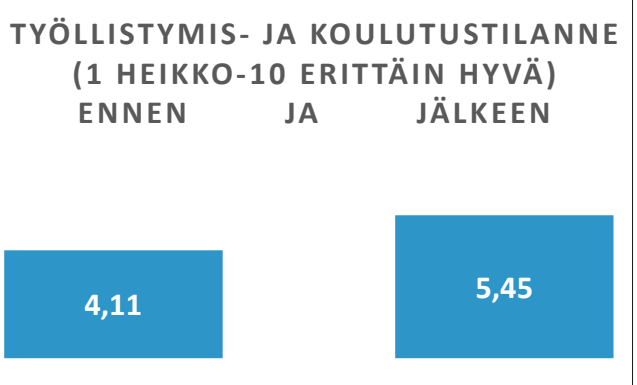

Kuvio 2. Koettu työllistymis- ja koulutustilanne ennen sosiaalisen kuntoutuksen jaksoa ja sen jälkeen

ta on vaikutusta sillä, että työmarkkinatuki ei alene, jos kuukausitulo jää alle kolmensadan euron. Samoin perustulokokeilu, jossa kahdelletuhannelle satunnaisesti valitulle työmarkkinatuen saajalle myönnetään kuukausittain ehdoitta 560 euroa, mallintaa sitä, mikä merkitys tulonsiirtojärjestelmällä on osallistumiseen ja työssäkäyntiin. Kuitenkin yksilötason kannustavuuden lisäksi valtion ja kunnan välisellä vastuunjaolla on merkitystä.

Kuntatalouden kannalta on väliä sillä, että kunnan pitää maksaa merkittäviä osuuksia pitkäaikaistyöttömiensä työmarkkinatuista. Kun asiakas on työllistymistä edistävässä toiminnassa, kuten sosiaalisessa kuntoutuksessa, kunta on vapautettu tästä velvollisuudesta. Toiseksi kunta saa kuntouttavan työtoi-

Taulukko 3. Ohjautuminen sosiaalisen kuntoutuksen jakson jälkeen.

\begin{tabular}{|c|c|c|}
\hline Mihin sosiaalisen kuntoutuksen jälkeen? & $\%$ & $\mathrm{~N}$ \\
\hline Jatkoryhmä tai toinen sosiaalisen kuntoutuksen ryhmä & 36 & 272 \\
\hline Kuntouttavan työtoiminnan yksikkö & 36 & 271 \\
\hline Typa:n palvelut (työllisyyden hoidon yksikkö) & 2 & 18 \\
\hline Työkokeilu & 2 & 12 \\
\hline Koulutus & 2 & 14 \\
\hline Työ & 1 & 8 \\
\hline Eläkeselvittely & 3 & 25 \\
\hline Jatkaa TE-toimiston asiakkaana & 5 & 40 \\
\hline $\begin{array}{l}\text { Terveydenhoito (sis. terveydenhuollon, päihdekuntoutu } \\
\text { ja psykiatrisen hoidon) }\end{array}$ & 3 & 25 \\
\hline Sosiaalityön asiakkuus jatkuu & 3 & 23 \\
\hline Muu tai ei suunnitelmaa & 6 & 48 \\
\hline Yhteensä & 100 & 756 \\
\hline
\end{tabular}


minnan järjestämisestä valtion korvauksena 10,09 euroa toimintapäivää ja kutakin kuntouttavaan työtoimintaan osallistuvaa asiakasta kohti (THL 2015). Lisäksi sosiaaliseen kuntoutukseen osallistumalla työttömyysturvan maksamisen työssäolovelvoitteet täyttyvät. Kolmanneksi kunta säästää toimeentulotukimenoissa, koska osallistujista lähes kaikki saavat jakson ajan työmarkkinatukea, jonka piirissä jotkut asiakkaat eivät ole olleet ennen ryhmätoimintaa. Tämän lisäksi jotkut kurssilaisista jäävät jakson jälkeen työmarkkinatuen piiriin, vaikka he eivät olisi siihen olleet oikeutettuja ennen jaksoa.

Taloudellisten seikkojen lisäksi sosiaalinen kuntoutus on ajankohtaista monesta syystä. Kuntoutuksen kokonaisuudistus etenee osana sosiaali- ja terveyspalvelujen uudistamista, ja on tärkeää selvittää, miten kuntoutuksen kokonaisprosessi voidaan integroida osaksi toimivia sosiaali- ja terveyspalveluja (Poutiainen 2016). Lähiyhteisöjen murentuminen sekä väliinputoamisen vaara koventuneen kilpailun, nopean muutoksen ja taloudellisen niukkuuden yhteiskunnassa muuttavat asiakkaiden osallistumisen, selviytymisen sekä toiminta- ja työkyvyn kysymykset entistä monisäikeisemmiksi (Rajavaara \&t Karjalainen 2012). EVA:n tuoreen selvityksen mukaan työvoiman ulkopuolella on lähes 80000 työikäistä miestä (Pyykkönen ym. 2016). Mallia voi peilata myös ajankohtaiseen keskusteluun osallistumistulosta (Hiilamo ym. 2017)

Pitkäaikaisten ja ylisukupolvisten vaikutusten arviointi on vaativa mutta tärkeä osa sosiaalipolitiikan ja sosiaalityön onnistumista. Vaativuutta lisää se, että talousvaikutuksiin kytkeytyy inhimillisiä ja sosiaalisia näkökohtia. Tätä monisäikeistä dynamiikkaa kannattaisi tutkia tarkemmin. Tässä katsauksessa kuvattuun ryhmäosallistumiseen liittyvä hyvinvoinnin lisääntyminen voi tuottaa pitkäaikaisvaikutuksia, jotka voivat vähentää sairastavuutta ja erityissairaanhoidon tarvetta. Samoin lastensuojelun tarve voi vähentyä, jos vaikeuksissa olevilla vanhemmilla tai isovanhemmilla on sosiaalista tukea ja rakentavia tulevaisuudensuunnitelmia.

Kun toimeentulotuki siirtyi vuoden 2017 alusta Kelan maksettavaksi, kuntien sosiaalityöntekijöille vapautui aiempaa enemmän aikaa tukea aikuisasiakkaita muillakin tavoin kuin laskemalle heille toimeentulotukea. Uudessa tilanteessa sosiaalityöntekijät ja heidän esimiehensä tarvitsevat kuntouttavaan sosiaalityöhön koeteltuja toimintatapoja, joita on helppo ottaa käyttöön. Samoin kunnan sosiaalitoimi, työllisyyspalvelut ja kolmannen sektorin toimijat kaipaavat malleja, joiden avulla voidaan yhdessä torjua syrjäytymistä. Edellä kuvattu Tampereen sosiaalinen kuntoutus tarjoaa konkreettisia keinoja järjestää vaikuttavaa toimintaa pitkäaikaistyöttömille ja muille yhteiskunnan reunalla oleville.

\section{Lopuksi}

Vuosien työttömyyden vaikutus elämään on monitahoinen ja pahimmillaan musertava. Tampereen sosiaalisen kuntoutuksen malli palvelee laajaa ja monimuotoista vaikeimmin työllistyvien joukkoa. Voiko muutama tunti viikossa ohjattua ryhmätoimintaa kolmen kuukauden ajan muuttaa jotakin olennaista? Asiakkaiden myönteiset arviot toiminnasta ovat rohkaisevia. Monet rakenteet asiakkaiden elämässä pysyvät samoina, vaikka yksilö saisikin uusia keinoja ja resursseja parantaa elämäänsä. Silti kanssaihmisyyttä ja mahdollisuuksia korostava konkreettinen toimintamuoto antaa asiakkaille uskoa, toivoa ja uusia näkökulmia.

Tulosten merkitys: Tämä katsaus osoittaa, että pitkäaikaistyöttömät ovat halukkaita osallistumaan vapaaehtoisuuteen perustuvaan ryhmämuotoiseen kuntoutustoimintaan, joka yhdistelee sosiaaliohjausta ja asiakkaiden keskinäisen vuorovaikutuksen edistämistä. Arvioidun mallin perusteella sosiaalisen kuntoutuksen vaikutus on myönteinen asiakkaiden arjessa. Vaativasta lähtötilanteesta huolimatta kolme neljästä jatkaa aktivointitoimien piirissä, ja lopuista suuri osa jatkaa heidän tilanteeseensa sopivien sosiaali- tai terveyspalvelujen parissa. Tampereen sosiaalinen 
kuntoutus on merkittävä sosiaalityön toimintamuoto, jolla on valtakunnallista kukaties kansainvälistäkin - käyttöä.

Avainsanat: sosiaalinen kuntoutus, kuntouttava työtoiminta, osallisuus, toimintakyky, pärjääminen, aktivointi, vapaaehtoisuus

Kiitokset johtava sosiaalityöntekijä Tuija Rajalalle tutkimushankkeen tukemisesta. Lämpimät kiitokset käsikirjoituksen kommentoinnista sosiaalityöntekijöille Mira Kolajo, Heidi Korhonen, Hanna Niskanen ja Reetta Väisänen.

\section{Mikko Perkiö, YTT, yliopisto-opettaja, Global Health and Development, yhteiskuntatieteiden tiedekunta, Tampereen yliopisto}

\section{Annariina Koivu, FT, tutkijatohtori, Global Health and Development, yhteiskuntatieteiden tiedekunta, Tampereen yliopisto}

Jälkisanat: Jutun kirjoittamisen jälkeen on saatu tieto, että Tampereen sosiaalisen kuntoutuksen ryhmämuotoinen palvelu on päättynyt huhtikuun 2017 lopulla. Kirjoittajat pahoittelevat, että kunta on luopunut tästä tuloksekkaasta toimintatavasta.

\section{Lähteet}

Bhat CS (2010) Assisting Unemployed Adults Find Suitable Work: A Group Intervention Embedded in Community and Grounded in Social Action. Journal for Specialists in Group Work 35, 3, 246-254.

Creed PA, Machin MA, Hicks RE (1999) Improving mental health status and coping abilities for longterm unemployed youth using cognitive-behaviour therapy based training interventions. Journal of Organizational Behavior 20, 963-978.

Haapamäki M (2009) Sosiaalinen kuntoutus ja asiakkaiden vaikutusmahdollisuudet Koutsi-valmennukseen osallistuneiden kertomana. Pro Gradu. Tampereen yliopisto. Sosiaalipolitiikka.https:// tampub.uta.fi/bitstream/handle/10024/80732/gradu03657.pdf?sequence $=1$

Hiilamo H, Kathrin K, Moisio P, Babila Sama T, Lauronen J-P, Karimo A, Mäntyneva P, Parpo A, Aaltonen H (2017) Neljä osallistuvan sosiaaliturvan mallia. Valtioneuvoston selvitys- ja tutkimustoiminnan julkaisusarja 18. Helsinki.
Hodzic S, Ripolla P, Liraa E, Zenasnib F (2015) Can intervention in emotional competences increase employability prospects of unemployed adults? Journal of Vocational Behavior 88, 28-37.

Isola, A-M, Turunen E, Hiilamo H (2016) Miten köyhät selviytyvät Suomessa? Yhteiskuntapolitiikka 81, 2, 150-160.

Kananoja A (2012) Sosiaalinen kuntoutus ja sosiaalihuollon uudistuksen suunta. Kuntoutus 4, 35-40.

Kesä M, Kinnunen R, Ala-Kauhaluoma M, Laiho A, Müller J-E, Joutsen M (2013) Sosiaalisen Kuntoutuksen Selvitystyö. Tampereen kaupunki, Innolink, Sosiaalikehitys, Kuntoutussäätiö. http://tyollisyysportti-fi-bin.aldone.fi/@Bin/a4bc417d77fdfc283ac5c2d7775970d0/1422967346/application/ pdf/100268/Loppuraportti_TYPA_sosiaalinen\%20 kuntoutus_10092013.pdf

Kuvaja A (2012) Työnhakumotivaation dynamiikkaa: Näkökohtia motivaatiokysymysten käsittelystä sosiaalisessa kuntoutuksessa. Kuntoutus 4, 17-29.

Machin MA, Creed PA (2003) Understanding the differential benefits of training for the unemployed. Australian Journal of Psychology, 55, 104-113.

Perkiö M, Simula H (2004) Tampereen Matalan huumehoitomalli. A-klinikkasäätiö. Tiimi-lehti, 6, 4-7.

Poutiainen E (2016) Miten kuntoutukseen liittyvä tutkimus- ja kehittämistieto leviää ja tavoittaa tiedon soveltajat? Kuntoutus 2, 3-4.

Pyykkönen J, Myrskylä P, Haavisto I, Hiilamo H, Nord U (2016) Kadonneet Työmiehet. EVA-analyysi 54. http://www.eva.fi/wp-content/uploads/2017/02/ no_54.pdf

Rajavaara M, Karjalainen V (2012) Sosiaalinen kuntoutus lakisääteiseksi - mikä muuttuu? Kuntoutus 4, 3-4.

Silvonen J, Vuori J (1998) Työhön-ryhmien vaikutus työttömien masennusoireisiin. Sosiaali- ja terveysturvan tutkimuksia 34. Kansaneläkelaitos, Helsinki.

Tampereen kaupunki (2016) Avaimia arkeen. http:// www.tampere.fi/sosiaali-ja-terveyspalvelut/sosiaalinen-tuki-ja-toimeentulo/aikuissosiaalityo/ avaimia-arkeen.html

THL (2015) Kuntouttavan työtoiminnan käsikirja. http://www.thl.fi/fi/web/kuntouttavan-tyotoiminnan-kasikirja/kuntouttavan-tyotoiminnankasikirja/toiminnan-rahoitus. 